\title{
The Use of Plant Macrofossils for Paleoenvironmental Reconstructions in Southern European Peatlands
}

\author{
Martin Souto ${ }^{1, *}$, Daniel Castro ${ }^{1}$, Eduardo García-Rodeja ${ }^{2}$ and Xabier Pontevedra-Pombal ${ }^{2}$ \\ 1 Department Botánica, Fac. Bioloxía, Universidade de Santiago de Compostela, Campus Vida, 15782 Galicia, \\ Spain; daniel.castro.fernandez@usc.es \\ 2 Department Edafoloxía e Quimica Agrícola, Fac. Bioloxía, Universidade de Santiago de Compostela, \\ Campus Vida, 15782 Galicia, Spain; eduardo.garcia-rodeja@usc.es (E.G.-R.); xabier.pombal@usc.es (X.P.-P.) \\ * Correspondence: martin.souto@usc.es
}

Received: 2 July 2019; Accepted: 29 September 2019; Published: 1 October 2019

check for updates

\begin{abstract}
The analysis of plant macrofossils in peatland ecosystems has been widely used for the climatic and ecological reconstruction of the Holocene in the high latitudes of the northern hemisphere. By contrast, perhaps associated with rarity of these ecosystems, this proxy has barely been explored for southern Europe. In this work, a compilation and review of existing knowledge on the study of plant macrofossils of peatlands in southern Europe has been carried out, both from a paleoenvironmental perspective and in terms of biodiversity dynamics. Although small in surface area, the peatlands of southern Europe stand out for their diversity (botanical, edaphogenic, morphological, etc.), which has allowed the recovery of a large number of macrofossils from both vascular plants and bryophytes. The southern zone of Europe contains refuge zones with a high plant diversity that have not suffered the intense glaciation of the northern zones, this allows a continuous record since the beginning of the Holocene and the detection of climatic events in lower latitudes, where the ice recession was earlier.
\end{abstract}

Keywords: paleobotany; paleoclimatic reconstructions; plant remains; mires; bogs

\section{Introduction}

Peatland ecosystems occupy 3\% of the Earth's surface, around 420 million ha. mostly in the boreal zone of the northern hemisphere [1]. The distribution of these habitats has been reduced especially in southern Europe; c. $60 \%$ of European peatlands have been destroyed due to human activities [2,3]. The Habitats Directive 92/43/EEC of the European Union [4], considers peatlands as ecosystems of priority community interest, for which it is necessary to designate areas for their conservation.

Peatlands provide a detailed record of the climatic and ecological changes that occurred during the Holocene, because they preserve a continuous record of fossil remains in very good state of conservation [5,6]. There is a rich history of paleobotanical research in Europe focused on plant macrofossils, however, most of these studies consider fossils that are older than Holocene. The analysis of plant macrofossils has been commonly used in oceanic regions of Europe, mainly in Great Britain; however, despite the potential wealth of information there are few studies in peatlands of southern Europe. This region has a variety of peatlands, which provide habitats for numerous relict, disjunct and endemic species, and communities.

Holocene plant macrofossils in southern Europe are generally related to archaeological studies on the beginnings of agriculture, the expansion of different cereals, the diversity of food of different cultures, etc. In recent decades the interest in paleoenvironmental studies and the recognition of the value of information on flora and vegetation of past times, has led to increased studies on plant macrofossils, within the time frame of the Holocene. 
Plant macrofossil records are spatially much more precise than the pollen data. They present great taxonomic resolution, if the samples are well preserved, they can be identified at species level such as Carex or Potamogeton $[7,8]$. They are a valuable tool for obtaining good radiocarbon dating $[9,10]$ and are very helpful in the reconstruction of the forest development, tree and, timber line shifts in the mountain ecosystems [11] or to reconstruct trails of plants spreading and migration. Another use of these macrofossils is to deliver reference conditions during reconstruction of the vegetation population, that is necessary for restoration process [12,13]. Southern Europe is heavily populated and in recent decades many of these ecosystems have been exposed to human land use change (peat bedding, grazing, fuel, acidifying, etc.), which has affected species composition.

Analyses of plant macrofossils from peat cores provides a high-resolution record of vegetation change through time. The study of peat slices 1 or $2 \mathrm{~cm}$ thin, allows to obtain data for very small time escals. This is especially valuable to reconstruct local plant development. Peat accumulation is primarily the result of the slow decay rate of the species in the plant communities under certain climate and anoxic conditions [14,15]. The more decomposition, the less identifiable macrofossils remain in the peat, however a biochemical footprint remains, and in recent decades numerous works have focused on identifying some of the major changes in vegetation by analyzing these biomarkers by pirolisis-GC/MS [16-21].

In this paper, we will focus on plant macrofossils data. The existence of common or biogeographically conditioned patterns and the relevance of the data from the botanical and paleoenvironmental standpoint will be explored.

\section{Material and Methods}

Peatlands are widely distributed across northern Europe, however in the southern part its extension is much smaller, occupying mainly mountainous areas. We review the various types of peatland and lake systems along the continuum of terrestrialization. Occasionally some peaty paleo-deposit has been included, due to the paleoenvironmental interest of the identified macrofossils. Figure 1 shows the distribution of peatlands in Europe according to Moen et al. [22] the numbers refer to Table 1. All localities below $50^{\circ} \mathrm{N}$ parallel have been considered and a summary of basic core data grouped by zone is given in Table 1.

Only those studies that have explicitly processed and identified plant macrofossils have been included, excluding data provided by coals, oospores of Characeae, and invertebrate remains. The summary Tables 2-4 group the macrofossil taxa identified in each work and include the type of remains found through a series of abbreviations for vascular plants: Leaf (LF), stomata (ST), epidermis (E), needles (NE); rhizome (R), wood (W), cones (C), bud scales (BS), bark (BK), roots (R), seeds (S), fruit (F), these last two concepts appear often confused in the different identifications, are considered fruits, achenes, or nuts (nutles) of all Cyperaceae and many Rosaceae, as well as the cariopsis of Poaceae. In the case of Bryophyta, the filidia are more abundant in the remains and only in very well conserved peat do filidia, caulidia, or large fragments of moss appear and very rarely capsules and the term vegetative part (VP) has been chosen. Data referring to sclerotia (SCL) of fungi have been included, as they are large and common in numerous papers. 


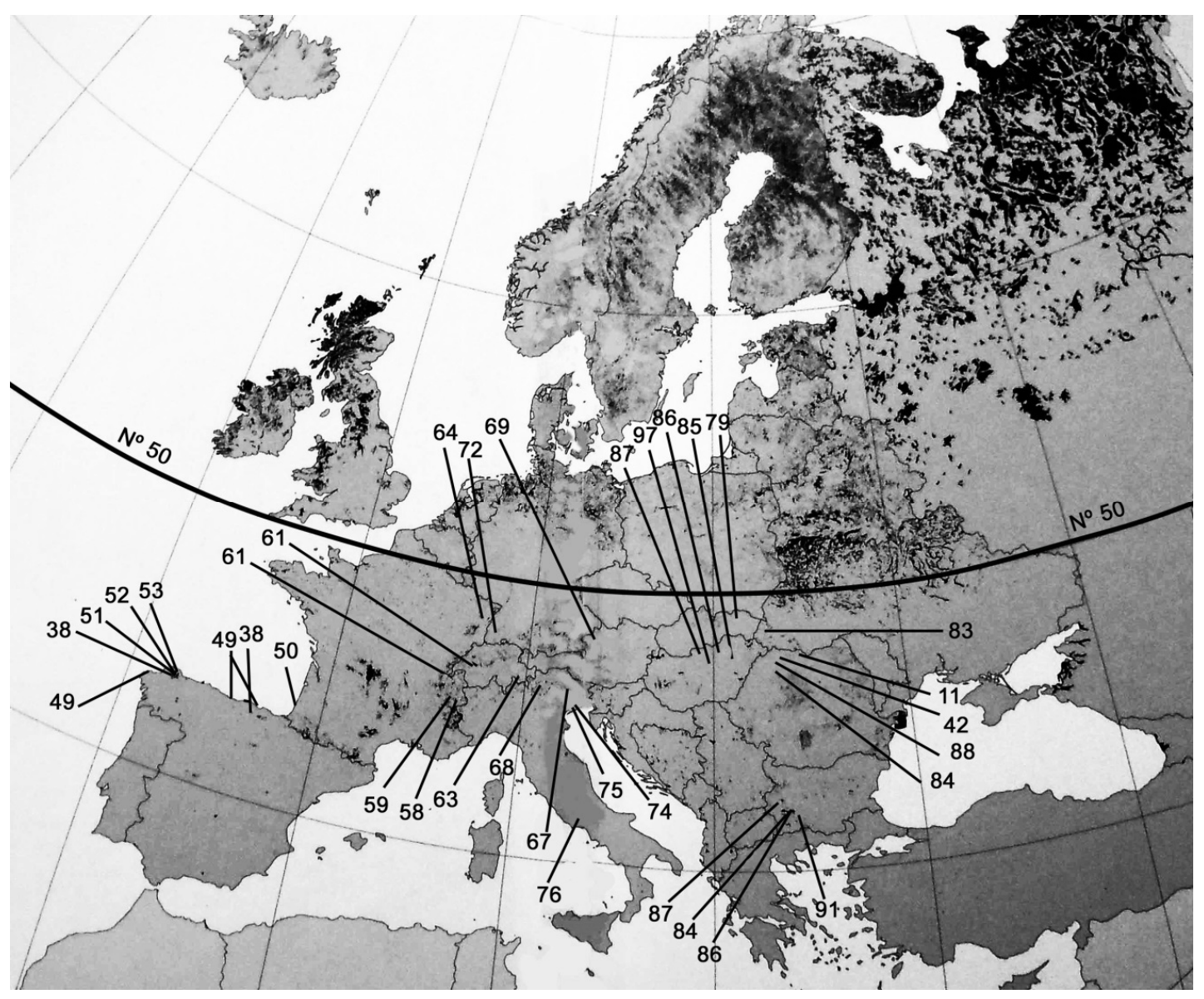

Figure 1. Distribution of peatlands in Europe and the location of sites mentioned in the text. The references correspond to the numbering in the bibliography (modified from Moen et al. 2017).

Table 1. Description of sites mentioned in the text. Ref: The references correspond to the numbering in the bibliography.

\begin{tabular}{|c|c|c|c|c|c|c|}
\hline SITE LOCATION & $\begin{array}{l}\text { DEPTH } \\
(\mathrm{cm})\end{array}$ & Yrs. Cal. BP & MATERIAL & $\begin{array}{c}\text { ALT } \\
\text { (m a.s.1.) }\end{array}$ & REF & AUTOR \\
\hline & & WEST ZONE & & & & \\
\hline $\begin{array}{l}\text { Zalama, De Ordunte Mts. } \\
\text { (ES) }\end{array}$ & 226 & 8000 & Peat & 1330 & 38 & Souto, 2018 \\
\hline $\begin{array}{c}\text { Borralleiras, Cabaleiros } \\
\text { Mts. (ES) }\end{array}$ & 230 & 5500 & Peat & 600 & 38 & Souto, 2018 \\
\hline $\begin{array}{c}\text { Pena da Cadela, Serra do } \\
\text { Xistral (ES) }\end{array}$ & 183 & 5500 & Peat & 970 & 51 & $\begin{array}{l}\text { Castro et al., } \\
2015\end{array}$ \\
\hline $\begin{array}{c}\text { Chan de Veiga Mol, Serra } \\
\text { do Xistral (ES) }\end{array}$ & 845 & 8000 & Peat & 695 & 52 & Castro, 2017 \\
\hline $\begin{array}{l}\text { Pedrido, Serra do Xistral } \\
\text { (ES) }\end{array}$ & 250 & 4750 & Peat & 770 & 53 & $\begin{array}{l}\text { Stefanini et al., } \\
2018\end{array}$ \\
\hline $\begin{array}{c}\text { Noja, Cantabric Coast } \\
\text { (ES) }\end{array}$ & 100 & $3200-4600$ & $\begin{array}{c}\text { Coast peat } \\
\text { deposit }\end{array}$ & 50 & 49 & $\begin{array}{l}\text { García et al., } \\
2008\end{array}$ \\
\hline $\begin{array}{l}\text { Merón, Cantabric Coast } \\
\text { (ES) }\end{array}$ & 20 & $6000-7000$ & $\begin{array}{l}\text { Coast peat } \\
\text { deposit }\end{array}$ & 50 & 49 & $\begin{array}{l}\text { García et al., } \\
2008\end{array}$ \\
\hline $\begin{array}{l}\text { Baldaio, Cantabric Coast } \\
\text { (ES) }\end{array}$ & 30 & 870 & $\begin{array}{l}\text { Coast peat } \\
\text { deposit }\end{array}$ & 25 & 49 & $\begin{array}{l}\text { García et al., } \\
2008\end{array}$ \\
\hline $\begin{array}{c}\text { Le Moura, Cantabric } \\
\text { Coast (FR) }\end{array}$ & 600 & 10,000 & Peat & & 50 & Oldfield, 1964 \\
\hline
\end{tabular}


Table 1. Cont.

\begin{tabular}{|c|c|c|c|c|c|c|}
\hline SITE LOCATION & $\begin{array}{l}\text { DEPTH } \\
(\mathrm{cm})\end{array}$ & Yrs. Cal. BP & MATERIAL & $\begin{array}{c}\text { ALT } \\
\text { (m a.s.1.) }\end{array}$ & REF & AUTOR \\
\hline \multicolumn{7}{|c|}{ CENTRAL ZONE } \\
\hline $\begin{array}{c}\text { Grande Basse, Vosges Mts. } \\
\text { (FR) }\end{array}$ & 200 & 3000 & Peat & 945 & 64 & Kalis et al., 2006 \\
\hline $\begin{array}{c}\text { Canard Ib, Taillefer } \\
\text { Massif (FR) }\end{array}$ & 125 & 10,000 & Peat & 2200 & 58 & Ponel et al., 1992 \\
\hline $\begin{array}{c}\text { Lac Lauzons, } \\
\text { Hautes-Alpes (FR) }\end{array}$ & 170 & 10,000 & Peat & 2180 & 59 & Ponel et al., 2011 \\
\hline $\begin{array}{l}\text { Egelsee-Moor Mire, } \\
\text { Salzburg (AT) }\end{array}$ & 600 & 10,000 & Peat & 700 & 69 & Krisai et al., 2016 \\
\hline $\begin{array}{l}\text { Fuorn Mire, Fuorn Valley } \\
\qquad(\mathrm{CH})\end{array}$ & 255 & 8500 & Peat-Gyttja & 1805 & 63 & Stahii et al., 2006 \\
\hline $\begin{array}{c}\text { Lac de Fully, Rhône } \\
\text { Valley }(\mathrm{CH})\end{array}$ & 270 & 11,000 & Gyttja & 2135 & 62 & $\begin{array}{l}\text { Finsinger and } \\
\text { Tinner, } 2007\end{array}$ \\
\hline Gerzensee (CH) & 190-200 & 11,500 & Gyttja & 630 & 61 & $\begin{array}{l}\text { Tobolski and } \\
\text { Ammann, } 2000\end{array}$ \\
\hline Leysin $(\mathrm{CH})$ & $320-350$ & $10,850-12,050$ & Gyttja & 1230 & 61 & $\begin{array}{l}\text { Tobolski and } \\
\text { Ammann, } 2000\end{array}$ \\
\hline $\begin{array}{l}\text { Northern Black Forest } \\
\text { (GR) }\end{array}$ & 80 & 2000 & Peat & 430 & 72 & $\begin{array}{l}\text { Hölzer and } \\
\text { Hólzer, } 2000\end{array}$ \\
\hline $\begin{array}{c}\text { Palughetto, Lapisina } \\
\text { Valley (IT) }\end{array}$ & 50 & 12,200 & Paleo peat & 1040 & 67 & $\begin{array}{l}\text { Avigliano et al., } \\
2000\end{array}$ \\
\hline $\begin{array}{c}\text { Totenmoos, South Tyrol } \\
\text { (IT) }\end{array}$ & 800 & 15,000 & Peat & 1718 & 68 & Heiss et al., 2005 \\
\hline $\begin{array}{c}\text { Paludetto S2, Venetian } \\
\text { plain (IT) }\end{array}$ & $500-1050$ & 8700 & Peat & 50 & 75 & Miola et al., 2010 \\
\hline $\begin{array}{l}\text { Fiorentina, Venetian plain } \\
\text { (IT) }\end{array}$ & $1100-1800$ & $3000-17,000$ & Peat-clay-silt & 50 & 74 & Miola et al., 2006 \\
\hline \multirow[t]{2}{*}{$\begin{array}{l}\text { La Rota, Posta Fibreno } \\
\text { (IT) }\end{array}$} & 400 & 600 & Peat & & 76 & $\begin{array}{l}\text { Zaccone et al., } \\
2017\end{array}$ \\
\hline & & EAST ZONE & & & & \\
\hline $\begin{array}{l}\text { Begbunar, Osogovo Mts } \\
\text { (BG) }\end{array}$ & 105 & 5000 & Peat & 1800 & 95 & $\begin{array}{l}\text { Lazarova et al., } \\
2015\end{array}$ \\
\hline $\begin{array}{l}\text { Lake Ostrezko, Rila Mts } \\
\text { (BG) }\end{array}$ & 200 & 6000 & Peat & 2340 & 92 & $\begin{array}{c}\text { Tonkov and } \\
\text { Marinova, } 2005\end{array}$ \\
\hline $\begin{array}{l}\text { Lake Besbog, Pirin Mts } \\
\text { (BG) }\end{array}$ & 380 & 15,000 & Peat-Gyttja & 2200 & 94 & $\begin{array}{l}\text { Stefanova et al., } \\
2006\end{array}$ \\
\hline Vodniza, Rila Mts (BG) & 500 & 9500 & Peat-Gyttja & 2113 & 91 & $\begin{array}{c}\text { Tonkov et al., } \\
2018\end{array}$ \\
\hline Tara, Mts. (RS) & 270 & 9000 & Peat & 1600 & 97 & $\begin{array}{c}\text { Fisinger et al., } \\
2017\end{array}$ \\
\hline Nagymohos (HU) & $140-280$ & $4000-7500$ & Peat & 300 & 85 & $\begin{array}{l}\text { Magyari et al., } \\
2001\end{array}$ \\
\hline $\begin{array}{c}\text { Báb-tava, Bereg Plain, } \\
(\mathrm{HU})\end{array}$ & $142-176$ & $1000-2300$ & Peat & 100 & 86 & $\begin{array}{l}\text { Magyari et al., } \\
2008\end{array}$ \\
\hline $\begin{array}{c}\text { Sirok Nyírjes-to, Mátra } \\
\text { Mts, (HU) }\end{array}$ & 400 & 9000 & Peat & $250 \mathrm{~m}$ & 42 & $\begin{array}{l}\text { Jakab \& Sümegi, } \\
2010\end{array}$ \\
\hline $\begin{array}{l}\text { Gärgäläu fen, Rodna Mts. } \\
\text { (RO) }\end{array}$ & 150 & 9500 & Peat & 1810 & 11 & $\begin{array}{l}\text { Feurdean et al., } \\
\qquad 2016\end{array}$ \\
\hline $\begin{array}{l}\text { Valea Morii, North } \\
\text { western (RO) }\end{array}$ & 100 & 1100 & Peat & 640 & 88 & Galka et al., 2018 \\
\hline $\begin{array}{l}\text { Tăul Muced, Rodna Mts. } \\
\text { (RO) }\end{array}$ & 500 & 9000 & Peat & 1360 & 84 & Galka et al., 2016 \\
\hline $\begin{array}{l}\text { Belanské Lúky, Tatra Mts. } \\
\text { (SK) }\end{array}$ & 230 & 10,000 & Peat & 700 & 79 & $\begin{array}{l}\text { Hájková et al., } \\
2012\end{array}$ \\
\hline $\begin{array}{l}\text { Nádas Lake, Cserhát Mts. } \\
\text { (HU) }\end{array}$ & 340 & 8000 & Peat-Clay & 360 & 87 & $\begin{array}{l}\text { Sümegi et al., } \\
2009\end{array}$ \\
\hline Starunia, Carpathos (UA) & $300-500$ & 12,000 & Peat-Clay & 400 & 83 & $\begin{array}{l}\text { Stachowicz-Rybka } \\
\text { et al., } 2009\end{array}$ \\
\hline
\end{tabular}




\section{Results and Discussion}

Southern Europe contains numerous refugia with a high plant diversity that did not suffer the intense glaciation of the northern areas. The long persistence of peat "islands" has allowed the development of endemic plants and communities. The age of many of these peatlands, with records beginning before the Holocene (Table 1), allows a continuous recording and detection of climatic events in lower latitudes, where the ice recession was earlier. We can define three basic areas of study: A western area where most peatland habitats are mainly on the Iberian Peninsula; a central area in the Alps; and an eastern area that encompasses the Carpathians and Balkans.

\subsection{Problems in the Identification of Plant Macrofossils}

The analysis of macrofossils is not a technique with a complicated methodology, nor does it require great investment, or equipment, but it does require expert knowledge in botany (taxonomy), plant histology (morphology), and plant ecology.

The identification of plant macrofossils is based on comparisons with published descriptions and illustrations and the use of reference material. Few publications cover the range of plant material found in peatlands and in many cases corresponds to works from Russia [23-26] or northern Europe [27-31].

An important component of the remains preserved in peat are seeds and fruits, whose identification is easy from monographs of each botanical group; some families or typical genus of peatlands have been studied from this point of view, as for example Cyperaceae [32]; Juncus [33]; Vaccinium [34]; Menyanthes [35]; or Betula [36].

Some species are only represented by fruits and seeds (e.g., Drosera). These are often herbaceous species with small or delicate vegetative tissues (Figure 2). Other species, such as Eriophorum have resistant and perennial organs; the macrofossils found in the fossil record correspond mainly to remains of subterranean organs, roots, rhizomes, or basal areas of aerial parts and occasionally fruits (Figure 2), its identification depends on the epidermal cell pattern, stomas, hairs, or foliar margin and when not enough diagnostic characters of the species are preserved its identification results more difficult. For plant macrofossils found in ombrophic peatlands, descriptive and illustrated work by Souto et al. [37] can be consulted.
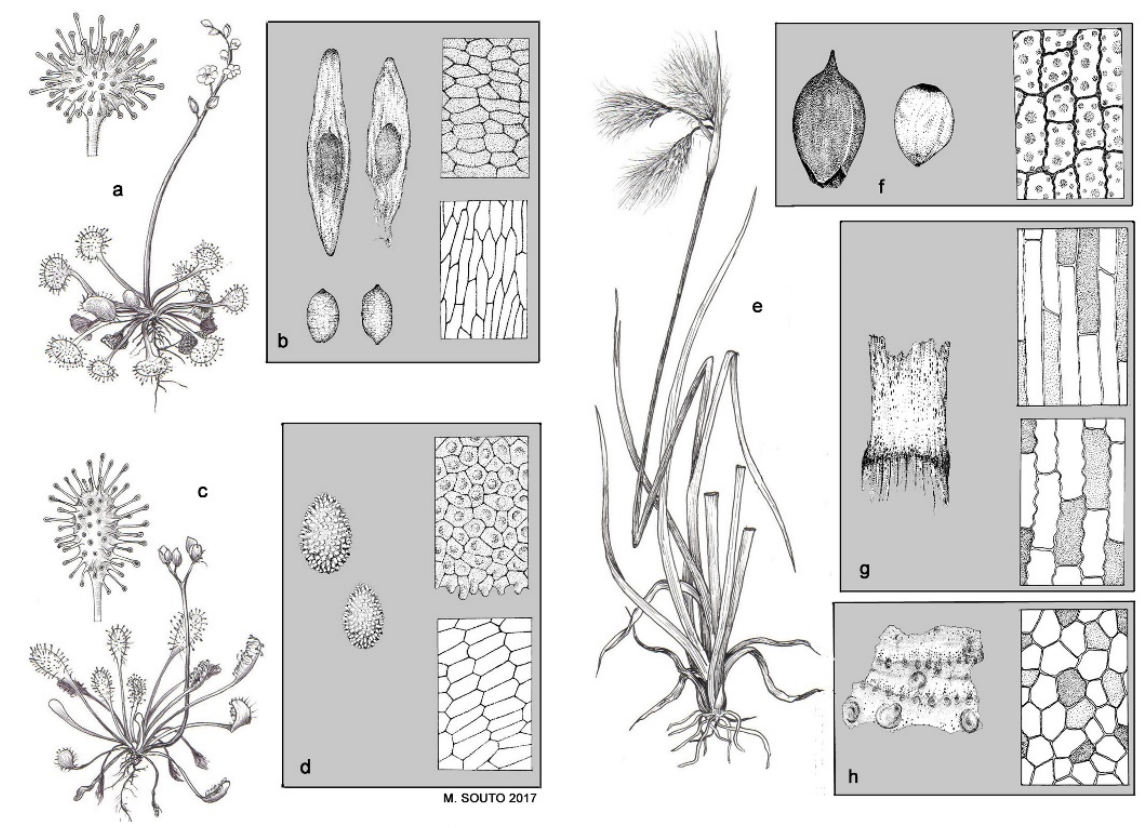

Figure 2. Fresh plants and corresponding macrofossils: Drosera rotundifolia (a) habit, (b) seeds; Drosera intermedia (c) habit, (d) seeds; Eriophorum sp (e) habit, (f) achenes, (g) remains of stems, (h) remains of rhizomes (Souto, 2018) [38]. 
The bryophytes are relatively easy to identify, since the determination of material in vivo is based mainly on the anatomy of the leaves and on their small size and it is common that they are well conserved in the peat. Sometimes they are altered by decay, keeping only certain parts, such as the zones of insertion of filidia or only the caulidia (Figure 3). They are important components of peatland flora, so their identification in macrofossil studies is vital to the interpretation of these habitats [39-42]. A detailed description of fossil bryophytes for ombrotrophic peatlands of the Cantabrian coast can be found in Souto et al. [43].

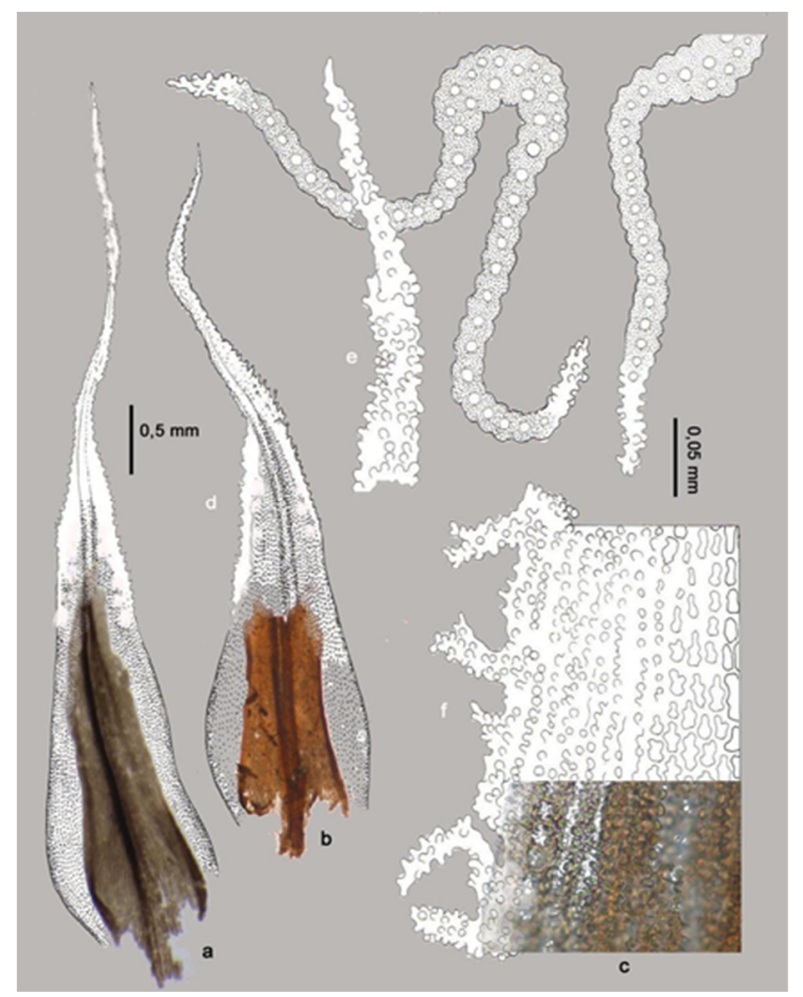

Figure 3. Example of differential degradation in Racomitrium. lanuginosum: $(\mathbf{a}, \mathbf{b})$ central parts of fossil leaves, (c) mid-leaf cells (fossils), (d,e,f) current leaves, hyaline apex and papillary rim (Souto, 2018) [38].

\subsection{Macrofossils: West Zone (Iberian Peninsula)}

In the Iberian Peninsula, the first studies of macrofossils in peatlands consisted of specific identifications, the works of Maldonado et al. [44] in Sierra de Gredos stand out. They prospected a wide area of peatlands and small lakes, located between 1100 and $1840 \mathrm{~m}$ a.s.1., collecting a great quantity of samples, among which stand out stumps in position of life, trunks of up to $5 \mathrm{~m}$ of length and $40 \mathrm{~cm}$ of diameter and numerous strobilus, dated between 850 and 5500 years cal BP. Other sampling areas include a synthesis on macrofossils collected in coastal areas, from the Cantabrian region to southern Portugal [45-48], the quaternary sediments that preserve peat bog deposits found in Noja, Oyambre-Merón, and Baldaio [49] stand out for their diversity in species. Although these works improve knowledge in the Iberian Peninsula mainly of forest species, they are not paleoenvironmental reconstructions of the same ecosystem over time. The work in the peatland of Le Moura [50] (Biarritz, south-west France), is the first that conserves a continuous sample of the flora since 10,000 years cal BP.

In the last decade, more precise paleobotanical investigations have been carried out, based on the analysis of plant macrofossils extracted from peat samples from different ombrotrophic peatlands in the north of the Peninsula [37,38,43,51-53]. These works provide a precise vision of the vegetation in each peatland, and the similarities between different proxy can offer more solid data for this region.

In the Iberian Peninsula, the different types of peatlands of the Atlantic region and some types of the Mediterranean and alpine region are present [54-57]. In the northwest of the Iberian Peninsula, 
the largest area is located, forming a complex system (macrotope) (Serras Septentrionais of Galicia, about 10,000 hectares). In this area, blanket bogs find their most southwestern distribution limit in Europe, they are currently restricted to mountain oceanic sectors, under an Atlantic hyperhumic climate very similar to that of northwestern Europe. Due to their ombrotrophic these peatlands are excellent paleoenvironmental archives and have been the subject of numerous studies from a multiproxy approach $[37,38,43,51-53]$.

The high resolution at which these analyses have been carried out (peat samples were studied every $1 \mathrm{~cm}$ deep), has made it possible to study the transition of the different plant communities over time, whether or not they represent autogenic successions. The different macrofossils found in these bogs (Table 2) allowed us to reconstruct with great accuracy the plant communities that developed in the peat bog over time. Highlighting that there are no remains of vegetation that may have reached the bog by transport from other places, such as pollen. All the taxa found correspond to species that are currently present in these peatlands. In these ombrotrophic peatlands, plant macrofossils show a great diversity of bryophytes, an herbaceous stratum dominated by Cyperaceae and Poaceae that accompanies different species of Ericaceae shrubs (Table 2). The quotation from Andromeda polifolia L. [53], a species not present in the peninsula, stands out, so this quotation is of doubtful interpretation. Many of these peatlands have a strong component of Poaceae and Cyperaceae. Their greatest contribution to the fossil record is in the form of remains of rhizomes, however these are difficult to identify at the species level. Future studies should focus on these structures due to the importance of this group of plants.

Table 2. Macrofossil taxa for ombrotrofic mires in North of Spain. Abbreviations: S-seeds, SCL—sclerotia, LF-leaf, F-fruit, R-Rhizome, W-wood, VP—vegetative part. Ref.: The references correspond to the numbering in the bibliography.

\begin{tabular}{|c|c|c|c|c|c|}
\hline REF. BIBLIOGRAPHY & [53] & [52] & [38] & [51] & [38] \\
\hline MACROFOSSIL TAXA & & & & & \\
\hline Betula pubescens & & $S$ & & & \\
\hline Ericaceae & LF, F, W & & $\begin{array}{c}\text { LF, F, } \\
W\end{array}$ & & \\
\hline Erica tetralix & LF & & & & $\mathrm{LF}, \mathrm{S}$ \\
\hline Erica mackaiana & LF, S & $\mathrm{LF}, \mathrm{S}$ & $\mathrm{LF}, \mathrm{S}$ & $\mathrm{LF}, \mathrm{S}$ & \\
\hline Calluna vulgaris & S & LF, S & LF, S & LF, S & $\mathrm{LF}, \mathrm{S}$ \\
\hline Andromeda polifolia & LF, S & & & & \\
\hline Daboecia cantabrica & & $S$ & & & S \\
\hline Vaccinium myrtillus & LF & & & & $\mathrm{LF}, \mathrm{W}$ \\
\hline Poaceae & $\mathrm{LF}$ & & & & \\
\hline Agrostis curtisii & & & & $\mathrm{LF}, \mathrm{R}$ & $\mathrm{LF}, \mathrm{R}$ \\
\hline Molinia caerulea & & $\mathrm{LF}, \mathrm{R}, \mathrm{F}$ & $\mathrm{LF}, \mathrm{R}, \mathrm{F}$ & $\mathrm{LF}, \mathrm{R}, \mathrm{F}$ & $\mathrm{LF}, \mathrm{R}, \mathrm{F}$ \\
\hline Potentilla erecta & & & $\mathrm{LF}, \mathrm{F}$ & $\mathrm{F}$ & $\mathrm{LF}, \mathrm{F}$ \\
\hline Drosera intermedia & & $S$ & & & \\
\hline Drosera rotundifolia & & S & S & S & S \\
\hline Narthecium ossifragum & & S & & S & S \\
\hline Caltha palustris & & & S & S & \\
\hline Cyperaceae & $\mathrm{LF}$ & $\mathrm{LF}, \mathrm{R}$ & $\mathrm{LF}, \mathrm{R}$ & $\mathrm{LF}, \mathrm{R}$ & \\
\hline Eriophorum sp. & S, LF & $\begin{array}{c}\mathrm{LF}, \mathrm{R}, \\
\mathrm{S}\end{array}$ & $\begin{array}{l}\text { LF, R, } \\
\quad S\end{array}$ & $\begin{array}{c}\text { LF, R, } \\
\quad S\end{array}$ & $\begin{array}{c}\text { S, LF, } \\
\text { R }\end{array}$ \\
\hline Carex echinata & & & $\mathrm{F}$ & & \\
\hline Carex demissa & & & & F & \\
\hline Carex binervis & & & $\mathrm{F}$ & & \\
\hline Carex durieui & & $\mathrm{F}$ & & $\mathrm{F}$ & \\
\hline Rhynchospora alba & & $\mathrm{F}$ & & & \\
\hline Trichophorum sp & LF & & & & \\
\hline
\end{tabular}


Table 2. Cont.

\begin{tabular}{|c|c|c|c|c|c|}
\hline REF. BIBLIOGRAPHY & [53] & [52] & [38] & [51] & [38] \\
\hline Luzula multiflora & & & & S & \\
\hline Juncus bulbosus & & $S$ & $S$ & $S$ & \\
\hline Juncus squarrosus & & & S & S & $S$ \\
\hline BRYOPHYTA & & & & & \\
\hline Aulacomnium palustre & & VP & & & VP \\
\hline Calliergonella cuspidata & & & & & VP \\
\hline Campylopus sp & VP & & VP & & \\
\hline Dicranum scoparium & & & & & VP \\
\hline Hypnum cupressiforme & VP & VP & VP & VP & VP \\
\hline Leucobryum juniperoideum & & VP & VP & VP & \\
\hline Polytrichum sp. & & & & & VP \\
\hline Racomitrium lanuginosum & & VP & & VP & $\mathrm{VP}$ \\
\hline Spagnum capillifolium & VP & & & & \\
\hline Spagnum tenellum & VP & VP & & VP & \\
\hline Sphagnum acutifolia & VP & & & & \\
\hline Sphagnum compactum & & VP & & VP & \\
\hline Sphagnum cuspidatum & & VP & & & \\
\hline Sphagnum molle & & & & VP & \\
\hline Sphagnum papillosum & & VP & & VP & \\
\hline Sphagnum sec. acutifolia & & VP & VP & VP & VP \\
\hline Sphagnum sec. cuspidata & VP & & & & VP \\
\hline Thuidium tamariscinum & & & & VP & \\
\hline Calypogeia sphagnicola & & & & VP & \\
\hline $\begin{array}{c}\text { Odontochisma sphagni } \\
\text { FUNGI }\end{array}$ & & VP & & & \\
\hline Cenoccocum geophilum & SCL & & SCL & & SCL \\
\hline
\end{tabular}

\subsection{Macrofossils: Central Zone (Alps)}

In France there are few works based on plant macrofossils. In most of the cases they have not been carried out in peatlands, among them, it can be highlighted from the work of Ponel et al. $[58,59]$ in the French Alps above $2000 \mathrm{~m}$ a.s.l. It is based on multiproxy analysis that combined palynology with identification of plant macrofossils and insects remains (mainly Coleoptera) this significantly improved the interpretations based on pollen analysis.

The Val-de-Lans basin (western French Alps) provides a rare opportunity to study Middle Pleistocene interglacial sediments, in this lacustrine interglacial deposit a rich flora of wetlands has been sampled [60]. Moreover, lacustrine deposits in Switzerland have recovered an important representation of the flora between the Younger Dryas and the Preboreal [61-63]. In the Vosges an interesting work [64] reconstructs fossil phytosociological communities, comparing groups of plant macrofossils to current communities.

In this central zone, many of the macrofossils are the remains of trees (Table 3) and in many of the peat cores one of the most studied groups is that of the Pinaceae $[65,66]$. The remains of conifers found in the excavation of a paleo-peatland near Venice [67] and in South Tyrol [68] with dates around the Younger Dryas stand out for their good conservation and abundance. 
Table 3. Macrofossil arboreal taxa for central zone. Abbreviations: S-seeds, F-fruit, W-wood, BS-bud scales; NE-needles; BK—bark; ST—stomata. Ref.: The references correspond to the numbering in the bibliography.

\begin{tabular}{|c|c|c|c|c|c|c|c|c|}
\hline REF. BIBLIOGRAPHY & [50] & [64] & [58] & [69] & [63] & [62] & [61] & [61] \\
\hline \multicolumn{9}{|l|}{ MACROFOSSIL TAXA } \\
\hline Pinus sp. & & & & & ST & S & & \\
\hline Pinus cembra & & & $\mathrm{BS}, \mathrm{NE}$ & & NE & $\mathrm{NE}, \mathrm{S}, \mathrm{W}$ & & \\
\hline Pinus mugo & & & & & $\mathrm{W}, \mathrm{NE}$ & & & \\
\hline Pinus uncinata & & & $\mathrm{NE}, \mathrm{S}$ & & & & & \\
\hline Pinus sylvestris & & & & & & & $\mathrm{NE}, \mathrm{BS}, \mathrm{S}$ & $\mathrm{NE}, \mathrm{BS}, \mathrm{S}$ \\
\hline Picea abies & & $\mathrm{NE}, \mathrm{S}$ & & $\mathrm{NE}, \mathrm{W}, \mathrm{S}$ & $\mathrm{NE}, \mathrm{ST}$ & $\mathrm{S}$ & & \\
\hline Abies alba & & $\mathrm{NE}$ & $\mathrm{NE}$ & & & & & \\
\hline Juniperus sp. & & & & & & W & & NE \\
\hline Juniperus communis & & & $\mathrm{NE}, \mathrm{S}$ & & & $\mathrm{NE}, \mathrm{W}$ & & \\
\hline Larix sp. & & & $\mathrm{Ne}$ & & & & & BS,BK \\
\hline Larix decidua & & & & & NE, ST & $\mathrm{NE}, \mathrm{S}, \mathrm{W}$ & & \\
\hline Salix sp. & BS & & & & & & & BS \\
\hline Populus tremula & & & & & & & $\mathrm{BS}, \mathrm{F}$ & $B S, F$ \\
\hline Alnus glutinosa & & S, BS & & $\mathrm{S}, \mathrm{W}$ & & & & \\
\hline Betula sp. & $\mathrm{F}, \mathrm{W}$ & & BS & $\mathrm{S}, \mathrm{W}$ & & & & \\
\hline Betula alba & & & $\mathrm{F}$ & & & F, BS & F, BS & $\mathrm{F}$ \\
\hline Betula carpatica & & & $\mathrm{F}$ & & & & & \\
\hline Betula pendula & & S, BS & & & & & & $\mathrm{F}$ \\
\hline Betula pubescens & & & & & & & F, BS & $\mathrm{F}$ \\
\hline Betula nana & & & & & & & & $\mathrm{F}$ \\
\hline Sambucus racemosa & & $\mathrm{S}$ & & & & & & \\
\hline Fagus sylvatica & & $B S, W, F$ & & & & & & \\
\hline
\end{tabular}

On the other hand, it is remarkable the absence of identified remains of bryophytes, of all the works studied in the area of the alps, only four [69-72] offer data of mosses. For the reconstructions based on the ecological needs of moss communities, Mitchell et al. [73] used bryophyte presence/absence data from sub-alpine peatlands in the SE Swiss Alps, and bootstrapping cross-validation showing that the best performing single-proxy transfer functions for both DWT (deep water table) and $\mathrm{pH}$ were those based on mosses.

In Italy marine transgression has been studied during the last $8000 \mathrm{BP}$ and as an effect on the development of marsh plant communities, in samples of more than $10 \mathrm{~m}$ the layers of peat were much rich in plant remains (Cyperaceae and Poaceae) [74,75]. "La Rota" a free-floating mire in lake of Posta Fibreno is an exceptional case of relic mire in central Italy, the top 220-230 cm of this free-floating mire consists almost exclusively of Sphagnum palustre [76].

\subsection{Macrofossils East Zone}

The numerous peatlands studied in the Carpathian area have provided a large amount of bryophyte data, both from the genus Sphagnum and Amblystegiaceae (Table 4.) Recent advances in biogeography include the application of macrofossil analysis to study the past distribution of many species and determine if a current species is relict. These models have made it possible to compare current distributions with past distributions, for example, relict bryophytes in the Czech Republic and Slovakia [77-79] and know the degree of regression that some taxa shows today [79]; in some cases it has been demonstrated the existence of an entire community that at present no longer exists as the case of Stygio-Caricion limosae alliance [80].

The diversity of peatlands in this area and the good conservation of aquatic and wetland taxa, has allowed us to reconstruct changes in the different paleoecosystems, based on the preferences of the different species [81-83]. These species indicate periods of temporary flooding or fluctuations of the water table, processes of terrestrialization or eutrophication, and autogenic plant succession [84-88]. 
The highest mountains of Bulgaria (Rila, Pirin, and the Rhodopes) with glacial relief forms with cirques, lakes, moraines, and trough river beds [89-91] where numerous fens are preserved, many of them above $2000 \mathrm{~m}$ a.s.l. These peatlands have been the subject of numerous studies [92-95]. That have shown the importance of plant macrofossil analyses in mountainous areas for the estimation of presence or absence of arborea taxa and reconstruct the history of the tree-line fluctuations [91,96,97]. The conclusions from pollen studies alone are more difficult in mountains than in the lowlands because of the importance of pollen transported over long distances [98].

Table 4. Bryophyta macrofossil. Abbreviations: VP-Vegetative parts. Ref.: The references correspond to the numbering in the bibliography.

\begin{tabular}{|c|c|c|c|c|c|c|c|}
\hline COD. SITE LOCATION & [79] & [85] & [97] & [87] & [86] & [84] & [88] \\
\hline \multicolumn{8}{|l|}{ MACROFOSSIL TAXA } \\
\hline Amblystegium kochii & & & & & VP & & \\
\hline Amblystegium serpens & & & & & VP & & \\
\hline Anomodon sp. & & & & & VP & & \\
\hline Aulacomnium palustre & & VP & & & VP & & \\
\hline Brachythecium mildeanum & & & & & VP & & \\
\hline Bryum pseudotriquetum & VP & & & & & & VP \\
\hline Calliergon giganteum & VP & & & & & & \\
\hline Calliergonella cuspidate & VP & & & & & & \\
\hline Campylium stellatum & VP & & & & & & VP \\
\hline Campylopus sp. & & & & & & VP & \\
\hline Depranocladus & & & & & & & VP \\
\hline Depranocladus aduncus & & & & VP & VP & & \\
\hline Herzogiella seligeri & & & & & VP & & \\
\hline Leucodon sciuroides & & & & & VP & & \\
\hline Meesia cf hexasticha & & & & VP & & & \\
\hline Meesia longiseta & & VP & VP & VP & VP & & \\
\hline Meesia trinquetra & & & VP & & & & \\
\hline Philonotis calcarean & VP & & & & & & \\
\hline Polytrichum strictum & VP & & & & & VP & \\
\hline Scorpidium cossonii & VP & & & & & & \\
\hline Scorpidium revolvens & & & & & VP & & \\
\hline Sphagnum sp. & VP & VP & & VP & & & \\
\hline Sphagnum acutifolia & & & & VP & & VP & \\
\hline Sphagnum angustifolium & & & & & & VP & \\
\hline Sphagnum cuspidatum & & & & & VP & & \\
\hline Sphagnum fuscum & VP & & & & & & \\
\hline Sphagnum magellanicum & & & & & VP & VP & \\
\hline Sphagnum obtusum & & & & & VP & & \\
\hline Sphagnum palustre & VP & VP & VP & VP & VP & & \\
\hline Sphagnum sec. cuspidate & & VP & VP & VP & & VP & \\
\hline Sphagnum squarrosum & & & & VP & VP & & \\
\hline Sphagnum subsecundum & & & & & VP & & \\
\hline Thuidium recognitum & & & & & VP & & \\
\hline Warnstorfia exannulata & & VP & VP & & & & VP \\
\hline Warnstorfia fluitans & & & VP & & & & \\
\hline
\end{tabular}

\section{Conclusions}

In the studies analyzed for southern Europe we find a great diversity of plant macrofossils. Around 200 taxa of vascular plants and around 50 of bryophytes. With the exception of arboreal and shrub taxa, which present a great diversity of preserved remains, most herbaceous species leave only seeds and fruits in the fossil record. The differential preservation of the different parts of each species must be taken into account for the correct identification of taxa.

High resolution sampling offers the possibility of studying the processes of autogenic succession in these ecosystems. The comparison of the evolution of the different types of peatlands could allow to 
find patterns and to separate these autogenic changes from climatic or anthropogenic changes. Future studies in the different areas where peatlands abound may help to consolidate the information offered by the different species.

Identification of indicator species, observations, and relationships between current vegetation can be used as a model analogous to past conditions, at least during the Holocene. The European Vegetation Archive (EVA: [99]) and European Vegetation Classification (EVC: [100]) are tools that allow us to know and classify the different groups of European habitats. Another model are macrofossil databases tracing the species distribution dynamics during glacial/interglacial cycles (http://www.sci.muni.cz/bot-any/mirecol/paleo [101]) and making the information more widely accessible to botanists and increasing confidence in paleoecological reconstructions and interpretations.

The study of current species based on their nutritional, environmental, or competitive requirements has provided very useful data for interpreting the different plant communities of the past, especially highlighting the data offered by bryophytes. The works where different proxies are used; allowing to test from different points of view the different hypotheses formulated on the observed environmental changes. In recent years, numerous investigations have been conducted in analyzing other proxy evidence include diatoms, mollusca, fungal remains, ostracods, cladocera, insect remains, and tecameba.

The rarity of these habitats in southern Europe, makes them a valuable resource for study and their present and past diversity must be preserved. All this information obtained from plant macrofossils, apart from studying the dynamics of the vegetation of the past, can also serve to discover future changes and develop programs for the restoration of ecosystems that are realistic and viable over time [102,103]. These habitats are very scarce and are in serious danger in southern Europe.

Author Contributions: Conceptualization, X.P.-P.; Methodology, D.C. and M.S.; Investigation, M.S.; Writing—original draft preparation, M.S.; Writing—review and editing, M.S., E.G.-R., and X.P.-P.; Supervision, E.G.-R. and X.P.-P.

Funding: This research was made possible through receipt of a grant awarded by the Xunta de Galicia (project: INCITE09-200-019-PR) and through the support for "Consolidación e Estructuración 2018 GRC GI-1243-GEMAP, ED431C 2018/32".

Conflicts of Interest: The authors declare no conflict of interest.

\section{References}

1. Clymo, R.S. Peat. In Ecosystems of the World. Mires: Swamp, Bog, Fen and Moor; Gore, A.J.P., Ed.; Elsevier: Amsterdam, The Netherlands, 1983; Volume 4A, pp. 159-224.

2. Joosten, H. Mires in Europe: A preliminary status report. Int. Mire Conserv. Group Memb. Newslett. 1997, 3, 10-13.

3. Joosten, H. Peat the final frontier: Mires and peatlands outside the tropics. In Peatlands under Pressure. Arctic to Tropical Peatlands; Maltby, E., Maclean, L., Eds.; Royal Holloway Institute for Environmental Research: Egham, UK, 1999; pp. 9-17.

4. European Commission. European Commission Interpretation Manual of European Union Habitats, Vers. EUR28; European Commission, DG Environment: Brussel, Belgium, 2013.

5. Barber, K.E.; Chambers, F.M.; Maddy, D.; Stoneman, R.E.; Brew, J.S. A sensitive highresolution record of late Holocene climate change from a raised bog in northern England. Holocene 1994, 4, 198-205. [CrossRef]

6. Blackford, J. Palaeoclimatic records from peat bogs. Trends Ecol. Evol. 2000, 15, 193-198. [CrossRef]

7. Birks, H.H.; Birks, H.J.B. Future uses of pollen analysis must include plant macrofossils. J. Biogeogr. 2000, 27, 31-35. [CrossRef]

8. Birks, H.H.; Birks, H.J.B. Reconstructing Holocene climates from pollen and plant macrofossils. In Global Change in the Holocene; Mackay, A., Battarbee, R.W., Birks, H.J.B., Oldfield, F., Eds.; Arnold: London, UK, 2003; pp. 342-357.

9. Kołaczek, P.; Gałka, M.; Apolinarska, K.; Gębica, P.; Superson, S.; Michno, A.; Harmata, K.; Szczepanek, K.; Płóciennik, M.; Gasiorowski, M.; et al. Lost in dating-Problems with the absolute chronologies and sedimentation rates of late glacial and early Holocene oxbow lake deposits in Central Europe. Quat. Geochronol. 2017, 41, 187-201. [CrossRef] 
10. Kołaczek, P.; Gałka, M.; Lamentowiczac, M.; Marcisz, K.; Kajukało-Drygalska, K.; Karpińska-Kołaczeka, M. Increased radiocarbon dating resolution of ombrotrophic peat profiles reveals periods of disturbance which were previously undetected. Quat. Geochronol. 2019, 52, 21-28. [CrossRef]

11. Feurdean, A.; Gałka, M.; Tanţău, I.; Geantă, A.; Hutchinson, S.M.; Hickler, T. Tree and timberline shifts in the northern Romanian Carpathians during the Holocene and the responses to environmental changes. Quat. Sci. Rev. 2016, 134, 100-113. [CrossRef]

12. Gałka, M.; Tobolski, K.; Górska, A.; Lamentowicz, M. Resilience of plant and testate amoeba communities after climatic and anthropogenic disturbances in a Baltic bog in Northern Poland: Implications for ecological restoration. Holocene 2017, 27, 130-141. [CrossRef]

13. Gałka, M.; Tobolski, K.; Lamentowicz, L.; Ersek, V.; Jaseey, V.E.; van der Knaap, W.O.; Lamentowicz, M. Unveiling exceptional Baltic bog ecohydrology, autogenic succession and climate change during the last 2000 years in CE Europe using replicate cores, multi-proxy data and functional traits of testate amoebae. Quat. Sci. Rev. 2017, 156, 90-106. [CrossRef]

14. Coulson, J.C.; Butterfield, J. An investigation of the biotic factors determining the rates of plant decomposition on blanket bog. J. Ecol. 1978, 66, 631-650. [CrossRef]

15. Yeloff, D.; Mauquoy, D. The influence of vegetation composition on peat humification: Implications for palaeoclimatic studies. Boreas 2006, 35, 662-673. [CrossRef]

16. Buurman, P.; Nierop, K.G.J.; Pontevedra-Pombal, X.; Martínez-Cortizas, A. Molecular chemistry by pyrolysis-GC/MS of selected samples of the Penido Vello peat deposit, Galicia, NW Spain. In Peatlands: Basin Evolution and Repositories of Records of Environmental and Climate Changes; Martini, I.P., Martínez, A., Chesworth, W., Eds.; Elsevier: London, UK, 2006; pp. 219-242.

17. Disnar, J.R.; Jacob, J.; Morched-Issa, M.; Lottier, N.; Arnaud, F. Assessment of peat quality by molecular and bulk geochemical analysis: Application to the Holocene record of the Chautagne marsh (Haute Savoie, France). Chem. Geol. 2008, 254, 101-112. [CrossRef]

18. Ortiz, J.E.; Gallego, J.L.R.; Torres, T.; Díaz-Bautista, A.; Sierra, C. Palaeoenvironmental reconstruction of Northern Spain during the last $8000 \mathrm{cal}$ yr BP based on the biomarker content of the Roñanzas peat bog (Asturias). Org. Geochem. 2010, 41, 454-466. [CrossRef]

19. Schellekens, J.; Buurman, P.; Fraga, I.; Martínez-Cortizas, A. Holocene vegetation and hydrologic changes inferred from molecular vegetation markers in peat, Penido Vello (Galicia, Spain). Palaeogeogr. Palaeoclimatol. Palaeoecol. 2011, 299, 56-69. [CrossRef]

20. Schellekens, J.; Buurman, P.; Kuyper, T.W.; Abbott, G.D.; Pontevedra-Pombal, X.; Martínez-Cortizas, A. Influence of source vegetation and redox conditions on lignin-based decomposition proxies in graminoid-dominated ombrotrophic peat (Penido Vello, NWSpain). Geoderma 2015, 237, 270-282. [CrossRef]

21. Schellekens, J.; Bradley, J.A.; Kuyper, T.W.; Fraga, I.; Pontevedra-Pombal, X.; Vidal-Torrado, P.; Abbott, G.D.; Peter Buurman, P. The use of plant-specific pyrolysis products as biomarkers in peat deposits. Quat. Sci. Rev. 2015, 123, 254-264. [CrossRef]

22. Moen, A.; Joosten, H.; Tanneberger, F. Mire diversity in Europe: Mire regionality. In Mires and Peatlands of Europe: Status, Distribution, and Nature Conservation; Joosten, H., Tanneberger, F., Moen, A., Eds.; Schweizerbart Science Publishers: Stuttgart, Germany, 2017; pp. 97-149.

23. Katz, N.J.; Katz, S.V.; Kipiani, M.G. Atlas and Keys of Fruits and Seeds Occurring in the Quaternary Deposits of the USSR; Publishing House Nauka: Moscow, Russia, 1965; pp. 1-367.

24. Katz, N.J.; Katz, S.V.; Skobeyeva, E.I. Atlas of Plant Remains in Peat Soil; Publishing House Nauka: Moscow, Russia, 1977; p. 736.

25. Velichkevich, F.U.; Zastawniak, E. Atlas of the Pleistocene Vascular Plant Macrofossils of Central and Eastern Europe. Part 1: Pteridophytes and Monocotylendons; Polish Academy of Sciences, W Szafer Institute of Botany: Krakow, Poland, 2006.

26. Velichkevich, F.U.; Zastawniak, E. Atlas of the Pleistocene Vascular Plant Macrofossils of Central and Eastern Europe. Part 2: Pteridophytes and Monocotylendons; Polish Academy of Sciences, W Szafer Institute of Botany: Krakow, Poland, 2008.

27. Godwin, H. The History of the British Flora: A Factual Basis for Phytogeography; Cambridge University Press: Cambridge, UK, 1975

28. Grosse-Brauckmann, G. Über pflanzliche Makrofossilien mitteleuropäischer Torfe. I. Gewebereste krautiger Pflanzen und ihre Merkmale. Telma 1972, 2, 19-55. 
29. Grosse-Brauckmann, G. Über pflanzliche Makrofossilien mitteleuropäischer Torfe. II. Weitere Reste (Früchte und Samen, Moose u.a.) und ihre Bestimmungsmöglichkeiten. Telma 1974, 4, 51-117.

30. Grosse-Brauckmann, G.; Streitz, B. Pflanzliche Makrofossilien mitteleuropäischer Torfe. III. Früchte, Samen undeinige Gewebe (Fotos von fossilen Pflanzenresten). Telma 1992, 22, 53-102.

31. Mauquoy, D.; Van Geel, B. Plant macrofossil methods and studies: Mire and peat macros. In Encyclopedia of Quaternary Science; Elias, S.A., Ed.; Elsevier Science: Amsterdam, The Netherlands, 2007; pp. 2315-2336.

32. Berggren, G. Atlas of Seeds and Small Fruits of Northwest-European Plant Species, Part 2. Cyperaceae; Swedish Natural Science Research Council: Stockholm, Sweden, 1969; pp. 1-107.

33. Körber-Grohne, U. Bestimmungsschlüssel für subfossile Juncus-samen und Gramineen-Früchtchen (Identification keys for subfossil Juncus seeds and grasses fruits). In Probleme der Küstenforschung im Sïdlichen Nordseegebiet (Problems of Coastal Research in the Southern North Sea Area); Haarnagel, W., Ed.; Lax: Hildesheim, Germany, 1964; Volume 1, pp. 1-47.

34. Tallantire, P.A. Provisional key for the identification of sub-fossil seeds of Vaccinium spp. Folia Quat. 1976, 47, $39-40$.

35. Truchanowiczówna, J. Fossil seeds of the genus Menyanthes in Eurasia. Acta Paleobot. 1964, 5, $25-69$.

36. Bialobrzeska, M.; Truchanowiczówna, J. Zmiennose ksztaltu owoców i lusek europejskich brzóz (Betula L.) oraz oznaczanie ich w stanie kopalnym. (The variability of shape of fruits and scales of the European birches (Betula L.) and their determination in fossil materials.). Mon. Bot. 1964, 9, 1-93.

37. Souto, M.; Castro, D.; Pontevedra-Pombal, X.; Garcia-Rodeja, E.; Fraga, M.I. Characterisation of Holocene plant macrofossils from North Spanish ombrotrofic mires: Vascular plants. Mires Peat 2016, 18, 1-21.

38. Souto, M. Reconstrucción Paleoambiental de Turberas del Norte de la Península Ibérica Mediante Análisis de Macrofósiles Vegetales y Grado de Humificación de la Turba. Ph.D. Thesis, Universidade de Santiago de Compostela, Santiago, Spain, 2018; pp. 1-207.

39. Birks, H.J.B. Quaternary bryophyte palaeoecology. In Bryophyte Ecology; Smith, A.J.E., Ed.; Chapman \& Hall: London, UK, 1982; pp. 473-490.

40. Barry, T.A.; Synnott, D.M. Further studies into bryophyte occurrence and succession in the Hochmoor peat types of Ireland. Glasra 1987, 10,1-21.

41. Tallis, J.H. Climate and erosion signals in British blanket peats: The significance of Racomitrium lanuginosum remains. J. Ecol. 1995, 83, 1021-1030. [CrossRef]

42. Jakab, G.; Sümegi, P. The role of bryophyte paleoecology in quaternary climate reconstructions. In Bryophyte Ecology and Climate Change; Tuba, Z., Slack, N.G., Stark, Y.R., Eds.; Cambridge University Press: Cambridge, UK, 2010; pp. 335-358.

43. Souto, M.; Castro, D.; Pontevedra-Pombal, X.; Garcia-Rodeja, E.; Fraga, M.I. Characterisation of Holocene plant macrofossils from North Spanish ombrotrofic mires: Bryophytes. Mires Peat 2017, 19, 1-12.

44. Maldonado, F.J.; Roch, V.; Rubiales, J.M.; Morla, C.; García-Amorena, I. Caracterización y Significación de los Yacimientos Paleobotánicos (Paleoxilológicos) de la Sierra de Gredos. In Proceedings of the IV Congreso Forestal Nacional, Zaragoza, Spain, 26-30 September 2005.

45. García-Antón, M.; Franco Múgica, F.; Maldonado Ruiz, J.; Morla Juaristi, C.; Sainz Ollero, H. Una secuencia polínica en Quintana Redonda (Soria). Evolución holocena del tapiz vegetal en el Sistema Ibérico Septentrional. An. Jard. Bot. 1995, 52, 187-195.

46. Muñoz Sobrino, C.; Ramil Rego, P.; Delibes de Castro, G.; Rojo Guerra, M. Datos paleobotánicos sobre la turbera de la Piedra (Páramo de Tozo, Burgos). In Biogeografía Pleistocena-Holocena de la Península Ibérica; Ramil Rego, P., Fernández Rodríguez, C., Rodríguez Guitián, M., Eds.; Xunta de Galicia: Santiago, Spain, 1996; pp. 149-162.

47. Roig, S.; Gómez Manzaneque, F.; Masedo, F.; Morla, C.; Sanchez Hernando, L.J. Estudio paleobotánico de estróbilos y maderas subfósiles holocenas en el yacimiento de Cevico Navero (Palencia, España). An. Jard. Bot. 1997, 55, 111-123.

48. Alcalde, C.; García-Amorena, I.; Gómez Manzaneque, F.; Maldonado, J.; Morla, C.; Postigo Mijarra, J.M. Estudio de los macrorrestos vegetales del yacimiento de Lomilla (Aguilar de Campo, Palencia, España). An. Jard. Bot. 2000, 59, 101-112.

49. García-Amorena, I.; Morla, C.; Rubiales, J.M.; Gómez Manzaneque, F. Taxonomic composition of the Holocene forests of the northern coast of Spain, as determined from their macroremains. Holocene 2008, 18, 819-829. [CrossRef] 
50. Oldfield, F. Late-quaternary deposits at le Moura, Biarritz, south-west France. New Phytol. 1964, 63, 374-409. [CrossRef]

51. Castro, D.; Souto, M.; Garcia-Rodeja, E.; Pontevedra-Pombal, X.; Fraga, M.I. Climate change records between the mid and late Holocene in a peat bog from Serra do Xistral (SW Europe) using plant macrofossils and peat humification analyses. Palaeogeogr. Palaeoclimatol. Palaeoecol. 2015, 420, 82-95. [CrossRef]

52. Castro, D. Reconstrucción Paleoambiental das Turbeiras da Serra do Xistral Mediante Análises Paleobotánicas. Ph.D. Thesis, Universidade de Santiago de Compostela, Santiago, Spain, 2017; p. 207.

53. Stefanini, B.S.; Oksanen, P.O.; Corcoran, J.P.; Mitchell, F.G. Appraising the cohesion of palaeoenvironmental reconstructions in north-west Spain since the mid-Holocene from a high temporal resolution multi-proxy peat record. Holocene 2018, 28, 681-694. [CrossRef]

54. Pontevedra-Pombal, X.; Nóvoa-Muñoz, J.C.; García-Rodeja, E.; Martínez-Cortizas, A. Mountain mires from Galicia (NW Spain). In Peatlands: Basin Evolution and Repositories of Records of Environmental and Climate Changes; Martini, I.P., Martínez, A., Chesworth, W., Eds.; Elsevier: London, UK, 2006; pp. 83-108.

55. Pontevedra-Pombal, X.; Castro, D.; Carballeira, R.; Souto, M.; López-Sáez, J.A.; Pérez-Díaz, S.; Fraga, M.I.; Valcárcel, M.; García-Rodeja, E. Iberian acid peatlands: Types, origin and general trends of development. Mires Peat 2017, 19, 1-19.

56. Pontevedra-Pombal, X. Turberas de Montaña de Galicia. Génesis, Propiedades y su Aplicación Como Registros Ambientales Geoquímicos. Ph.D. Thesis, Universidade de Santiago de Compostela, Santiago, Spain, 2002; pp. 1-483.

57. Heras, P.; Infante, M.; Pontevedra-Pombal, X.; Nóvoa-Muñoz, J.C. Mires and peatlands of Spain. In Mires and Peatlands of Europe: Status, Distribution, and Nature Conservation; Joosten, H., Tanneberger, F., Moen, A., Eds.; Schweizerbart Science Publishers: Stuttgart, Germany, 2017; pp. 639-656.

58. Ponel, P.; de Beaulieu, J.L.; Tobolsk, K. Holocene palaeoenvironments at the timberline in the taillefer massif, French Alps: A study of pollen, plant macrofossils and fossil insects. Holocene 1992, 2, 117-130. [CrossRef]

59. Ponel, P.; Court-Picon, M.; Badura, M.; Guiter, F.; de Beaulieu, J.L.; Andrieu-Ponel, V.; Djamali, M.; Leydet, M.; Gandouin, E.; Buttler, A. Holocene history of Lac des Lauzons (2180 m a.s.l.), reconstructed from multiproxy analyses of Coleoptera, plant macroremains and pollen (Hautes-Alpes, France). Holocene 2011, 21, 565-582. [CrossRef]

60. Field, M.H.; de Beaulieu, J.L.; Guiot, J.; Ponel, P. Middle Pleistocene deposits at La Cote, Val-de-Lans, Isère department, France: Plant macrofossil, palynological and fossil insect investigations. Palaeogeogr. Palaeoclimatol. Palaeoecol. 2000, 159, 53-83. [CrossRef]

61. Tobolski, K.; Ammann, B. Macrofossils as records of plant responses to rapid Late Glacial climatic changes at three sites in the Swiss Alps. Palaeogeogr. Palaeoclimatol. Palaeoecol. 2000, 159, 251-259. [CrossRef]

62. Finsinger, W.; Tinner, W. Pollen and plant macrofossils at Lac de Fully (2135 $\mathrm{m}$ a.s.l.): Holocene forest dynamics on a highland plateau in the Valais, Switzerland. Holocene 2007, 17, 1119-1127. [CrossRef]

63. Stähli, M.; Finsinger, W.; Tinner, W.; Allgöwer, B. Wildfire history and fire ecology of the Swiss National Park (Central Alps): New evidence from charcoal, polen and plant macrofossils. Holocene 2006, 16, 805-817. [CrossRef]

64. Kalis, A.J.; van der Knaap, W.O.; Schweizer, A.; Urz, R. Three thousand year succession of plant communities on a valley bottom in the Vosges Mountains, NE France, reconstructed from fossil pollen, plant macrofossils, and modern phytosociological communities. Veget. Hist. Archaeobot. 2006, 15, 377-390. [CrossRef]

65. Fauvart, N.; Ali, A.; Terral, J.F.; Roiron, P.; Blarquez, O.; Carcaillet, C. Holocene upper tree-limits of Pinus section sylvestris in the Western Alps as evidenced from travertine archives. Rev. Palaeobot. Palynol. 2012, 169, 96-102. [CrossRef]

66. Ammann, B.; van der Knaap, W.O.; Lang, G.; Gaillard, M.J.; Kaltenrieder, P.; Rösch, M.; Finsinger, W.; Wright, H.E.; Tinner, W. The potential of stomata analysis in conifers to estimate presence of conifer trees: Examples from the Alps. Veget. Hist. Archaeobot. 2014, 23, 249-264. [CrossRef]

67. Avigliano, R.; Anastasio, G.D.; Improta, S.; Peresani, M.; Ravazzi, C. A new late glacial to early Holocene palaeobotanical and archaeological record in the Eastern Pre-Alps: The Palughetto basin (Cansiglio Plateau, Italy). J. Quat. Sci. 2000, 15, 789-803. [CrossRef]

68. Heiss, A.G.; Kofler, W.; Oeggl, K. The ulten valley in South Tyrol, Italy: Vegetation and settlement history of the area, and macrofossil record from the Iron Age cult site of St. Walburg. Palyno Bull. 2005, 1, 63-73. 
69. Krisai, R.; van Leeuwen, J.F.; van der Knaap, W.O. Present-day vegetation and the Holocene and recent development of Egelsee-Moor, Salzburg province, Austria. Veget. Hist. Archaeobot. 2016, 25, 555-568. [CrossRef]

70. Sjögren, P.; Lamentowicz, M. Human and climatic impact on mires: A case study of Les Amburnex mire, Swiss Jura Mountains. Veget. Hist. Archaeobot. 2008, 17, 185-197. [CrossRef]

71. Krisai, R. Zum rezenten und subfossilen Vorkommen subarktischer Moose im salzburgisch/ oberösterreichischen Alpenvorland Vorh. Zool. Bot. Gos. Osterreich. 1985, 123, 143-150.

72. Hölzer, A.; Hölzer, A. Ein torfprofil vom westabfall der hornisgride im nordschwarzwald mit Messia triquetra Angstr. Carolinea 2000, 58, 139-148.

73. Mitchell, E.A.D.; Payne, R.J.; van der Knaap, W.O.; Lamentowicz, L.; Gabka, M.; Lamentowicz, M. The performance of single- and multi-proxy transfer functions (testate amoebae, bryophytes, vascular plants) for reconstructing mire surface wetness and pH. Quat. Res. 2013, 79, 6-13. [CrossRef]

74. Miola, A.; Bondesan, A.; Corain, L.; Favaretto, S.; Mozzi, P.; Piovan, S.; Sostizzo, I. Wetlands in the Venetian Po Plain (northeastern Italy) during the Last Glacial Maximum: Interplay between vegetation, hydrology and sedimentary environment. Rev. Palaeobot. Palynol. 2006, 141, 53-81. [CrossRef]

75. Miola, A.; Favaretto, S.; Sostizzo, I.; Valentini, G.; Asioli, A. Holocene salt marsh plant communities in the North Adriatic coastal plain (Italy) as reflected by pollen, non-pollen palynomorphs and plant macrofossil analyses. Veget. Hist. Archaeobot. 2010, 19, 513-529. [CrossRef]

76. Zaccone, C.; Lobianco, D.; Shotyk, W.; Ciavatta, C.; Appleby, P.; Brugiapaglia, E.; Casella, L.; Miano, T.M.; D'Orazio, V. Highly anomalous accumulation rates of $\mathrm{C}$ and $\mathrm{N}$ recorded by a relic, free- floating peatland in Central Italy. Sci. Rep. 2017, 7, 43040. [CrossRef] [PubMed]

77. Hájek, M.; Horsák, M.; Tichy, L.; Hájkova, P.; Díte, D.; Jamrichová, E. Testing a relict distributional pattern of fen plant and terrestrial snail species at the Holocene scale: A null model approach. J. Biogeogr. 2011, 38, 742-755. [CrossRef]

78. Hájková, P.; Stechová, T.; Soltés, R.; Smerdová, E.; Plesková, Z.; Díte, D.; Bradácová, J.; Mútnanová, M.; Singh, P.; Hájek, M. Using a new database of plant macrofossils of the Czech and Slovak Republics to compare past and present distributions of hypothetically relict fen mosses. Preslia 2018, 90, 367-386. [CrossRef]

79. Hájková, P.; Grootjans, A.B.; Lamentowicz, M.; Rybnickova, E.; Madaras, M.; Opravilova, V.; Hajkova, T. How a Sphagnum fuscum-dominated bog changed into a calcareous fen: The unique Holocene history of a Slovak spring-fed mire. J. Quat. Sci. 2012, 27, 233-243. [CrossRef]

80. Peterka, T.; Hájek, M.; Dítě, D.; Hájková, P.; Palpurina, S.; Goia, I.; Grulich, V.; Kalníková, V.; Plesková, Z.; Šímová, A.; et al. Relict occurrences of boreal brown-moss quaking rich fens in the Carpathians and adjacent territories. Folia Geobot. 2018, 53, 265-276. [CrossRef]

81. Kołaczek, P.; Gałka, M.; Apolinarska, K.; Płóciennik, M.; Gąsiorowski, M.; Brooks, S.J.; Hutchinson, S.M.; Karpińska-Kołaczek, M. A multi-proxy view of exceptionally early postglacial development of riparian woodlands with Ulmus in the Dniester River valley, western Ukraine. Rev. Palaeobot. Palynol. 2018, 250, 27-43. [CrossRef]

82. Šímová, A.; Pánek, T.; Gałka, M.; Zernitskaya, V.; Hájková, P.; Brodská, H.; Jamrichova, E.; Hájek, M. Landslides increased Holocene habitat diversity on a flysch bedrock in the Western Carpathians. Quat. Sci. Rev. 2019, 219, 68-83. [CrossRef]

83. Stachowicz-Rybka, R.; Gałka, M.; Alexandrowicz, W.P.; Alexandrowicz, S.W. Plant macrofossils and malacocoenoses of Quaternary mineral-organic sediments at Starunia palaeontological site and vicinity (Carpathian region, Ukraine). Ann. Soc. Geol. Pol. 2009, 79, 297-313.

84. Gałka, M.; Tantau, I.; Ersek, V.; Feurdean, A. A 9000 year record of cyclic vegetation changes identified in a montane peatland deposit located in the Eastern Carpathians (Central-Eastern Europe): Autogenic succession or regional climatic influences? Palaeogeogr. Palaeoclimatol. Palaeoecol. 2016, 449, 52-61. [CrossRef]

85. Magyari, E.; Sümegi, P.; Braun, M.; Jakab, G.; Molnar, M. Retarded wetland succession: Anthropogenic and climatic signals in a Holocene peat bog profile from north-east Hungary. J. Ecol. 2001, 89, 1019-1032. [CrossRef]

86. Magyari, E.; Jakab, G.; Sümegi, P.; Szoör, G.Y. Holocene vegetation dynamics im the Bereg Plain, NE Hungary-The Báb-tava pollen and plant macrofossil record. Acta GGM Debrecina 2008, 3, 33-50.

87. Sümegi, P.; Jakab, G.; Majkut, P.; Törocsik, T.; Zatykó, C. Middle age paleoecological and paleoclimatological reconstruction in the Carparthian Basin. Idöjárás 2009, 113, 265-298. 
88. Gałka, M.; Feurdean, A.; Hutchinson, S.; Milecka, K.; Tantau, I.; Apolinarska, K. Response of a spring-fed ecosystem in Central Eastern Europe (NW Romania) to climate changes during the last 4000 years: A high resolution multi-proxy reconstruction. Palaeogeogr. Palaeoclimatol. Palaeoecol. 2018, 504, 170-185. [CrossRef]

89. Bozilova, E.; Tonkov, S. Pollen from Lake Sedmo Rilsko reveals southeast European postglacial vegetation in the highest mountain area of the Balkans. New Phytol. 2000, 148, 315-325. [CrossRef]

90. Marinova, E.; Tonkov, S. Holocene vegetation history of the northwestern Pirin Mountain (Bulgaria). Plant fossil record from peat-bog Mozgovitsa. C. R. Acad. Bulg. Sci. 2012, 65, 1087-1094.

91. Tonkov, S.; Possnert, G.; Bazilova, E.; Marinova, E.; Pavlova, D. On the Holocene vegetation history of the Central Rila Mountains, Bulgaria: The palaeoecological record of peat bog Vodniza (2113 m). Rev. Palaeobot. Palynol. 2018, 250, 16-26. [CrossRef]

92. Tonkov, S.; Marinova, E. Pollen and plant macrofossil analyses of mid-Holocene ra-diocarbon dated profiles from two subalpine lakes in Rila Mountains, Bulgaria. Holocene 2005, 15, 663-671. [CrossRef]

93. Stefanova, I. New data on the late Holocene vegetative succession in the Northern Pirin Mts: Pollen and macrofossil analysis of depositions from peat bogs Goce Delchev and Visokata Ela. Phytol. Balc. 1997, 3, 53-63.

94. Stefanova, I.; Atanassova, J.; Delcheva, M.; Wright, H.E. Chronological framework for the Lateglacial pollen and macrofossil sequence in the Pirin Mountains, Bulgaria: Lake Besbog and Lake Kremensko-5. Holocene 2006, 16, 877-892. [CrossRef]

95. Lazarova, M.; Marinova, E.; Tonkov, S.; Snowball, I. A 5000-year pollen and plant macrofossil record from the Osogovo Mountain, Southwestern Bulgaria: Vegetation history and human impact. Rev. Palaeobot. Palynol. 2015, 223, 1-9. [CrossRef]

96. Stefanova, I.; Ammann, B. Lateglacial and Holocene vegetation belts in the Pirin Mountains (southwestern Bulgaria). Holocene 2003, 13, 97-107. [CrossRef]

97. Finsinger, W.; Morales-Molino, C.; Gałka, M.; Valsecchi, V.; Bojovic, S.; Tinner, W. Holocene vegetation and fire dynanics at Crveni Potok, a small mire in the Dinaric Alps (Tara National Park, Serbia). Quat. Sci. Rev. 2017, 167, 63-77. [CrossRef]

98. Markgraf, V. Pollen dispersal in a mountain area. Grana 1989, 19, 127-146. [CrossRef]

99. Chytrý, M.; Hennekens, S.M.; Jiménez-Alfaro, B.; Knollová, I.; Dengler, J.; Schaminée, J.H.J.; Aćić, S.; Agrillo, E.; Ambarlı, D.; Angelini, P.; et al. European vegetation archive (EVA): An integrated database of European vegetation plots. Appl. Veg. Sci. 2016, 19, 173-180. Available online: https://onlinelibrary.wiley. com/doi/full/10.1111/avsc.12191 (accessed on 8 October 2019). [CrossRef]

100. Mucina, L.; B€ultmann, H.; Dierßen, K.; Theurillat, J.-P.; Raus, T.; Carni, A.; Sumberova, K.; Willner, W.; Dengler, J.; Garcia, R.G.; et al. Vegetation of Europe: Hierarchical floristic classification system of vascular plant, bryophyte, lichen, and algal communities. Appl. Veg. Sci. 2016, 19, 3-264. [CrossRef]

101. Pokorná, A.; Dreslerová, D.; Křivánková, D. Archaeobotanical Database of the Czech Republic, an Interim Report. IANSA 2011, 1, 49-53. [CrossRef]

102. Rochefort, L.; Lode, E. Restoration of degraded boreal peatlands. In Boreal Peatland Ecosystems; Ecological Studies (Analysis and Synthesis); Wieder, R.K., Vitt, D.H., Eds.; Springer: Berlin/Heidelberg, Germany, 2006; Volume 188.

103. Schouten, M.G.C. (Ed.) Conservation and Restoration of Raised Bogs; Geological, Hydrological and Ecological Studies; Department of the Environment and Local Government Ireland, Geological Survey of Ireland: Staatsbosbeheer, The Netherlands, 2002.

(C) 2019 by the authors. Licensee MDPI, Basel, Switzerland. This article is an open access article distributed under the terms and conditions of the Creative Commons Attribution (CC BY) license (http://creativecommons.org/licenses/by/4.0/). 